\title{
An Investigation in to the Effectiveness of Participatory Budgeting in Achieving Community Development Goals in Port Loko District Council
}

\author{
Daniel E. M. Lavalie ${ }^{1 *}$, S. Subadra ${ }^{2}$, S. P. Sreekala ${ }^{3}$ \\ ${ }^{1}$ Research Scholar, School of Business Management, Department of Business Management, \\ Texila American University, Ghana \\ ${ }^{2}$ Assistant Professor \& Head Department of Commerce, NKR Government Arts College for \\ Women, Namakkal 637001 \\ ${ }^{3}$ Associate Professor, KPR Arts and Science College, Coimbatore
}

\begin{abstract}
The Sierra Leone local council is charged with the responsibilities to govern and look over the welfare of its citizens in its localities but has been faced with a lot of challenges ranging from limited finance, insufficient staff capacity, insufficient material resources, mobility, and little compliance from bigger MDAs in terms of control. Hence has raised effectiveness issues in council operations. With the implementation of participatory budgeting in Port, Loko District Council calls for a study with the objective to investigate the effectiveness and linearity of participatory budgeting in the achievement of community development goals in the Port Loko District Council. Purposive sampling was done and administered a survey questionnaire to 420 respondents in the Port Loko District. Simple linear regression and correlational tests were used to interpret and analyze the primary data using SPSS 16.0 software package. The data analyses found out that there was a mean agreement rate of 1.95, which indicated that the respondents agreed that participatory budgeting was effective. The hypothesis test, if the effectiveness of participatory budgeting in Port Loko District Council has an impact on the achievement of community development goals, the major finding in this research is that effectiveness of participatory budgeting significantly affects the achievement of community development goals in the council district and concludes that participatory budgeting implemented in the Port Loko District Council in relation to the achievement of community development goals is effective, has a positive relationship and a strong correlation between them.
\end{abstract}

Keywords: Community development, Effectiveness, Local council, Port Loko District Council, Participatory budgeting.

\section{Introduction}

Sierra Leone Local council is a sub-national Government created to govern its locality with a lot of functions to deliver to its subjects. According to the Local Government [1] in Section 20 , it is charged with the responsibility as the highest political authority in the locality which has legislative and executive powers to be exercised in accordance with the Act or any other enactment, and shall be responsible, generally for promoting the development of its locality, the welfare of the people in that locality with the resources and capacity at its disposal mobilise from the central government, its agencies, national and international organisations, and the private sector. According to [2], the purpose of local government is to provide an organised system where councils exercise their power and responsibilities to work together for peace, order and governance of their municipal districts and that effective local governments provide overall quality of life for the people who reside in their communities. 
With the above responsibilities charged with it, which is similar to that of the Port Loko district council, it has created room for the implementation of projects from both Government and Non-governmental agencies. As Participatory Budgeting (PB) been defined by [3], it is a form of citizen's participation in which citizens are involved in the process of deciding how public money is spent with the responsibility to scrutinize and monitor the process by following the allocation of the budgets also given to them.

According to [4], they said "participatory budgeting aims to democratically allocate public money for local services, enabling communities to decide how public funds are spent". Participatory budgeting in the sector of (Education, agriculture, and waste management) has been one of the projects implemented by Port Loko District Council. The councils are faced with a lot of challenges ranging from finance, that is, both grants and own sources revenue, insufficient staff capacity, insufficient material resources, and mobility problem, little compliance from bigger MDAs in terms of control [5]. Also, councils are faced with "limited revenue, high corruption, faulty administrative and management structure, low participation, poor working conditions, inexperience councillors, conflicting laws making execution difficult, low development plan execution because of lack of adequate knowledge in plans and policies and role misconception" [6]. As councils are operated with a lot of challenges ranging from late disbursement of funds, mobility, bureaucracy, and late implementations of projects, participatory budgeting implemented by Port Loko District Council is not an exception to the above constraints.

Therefore, the effectiveness as which is defined in business terms refers to the level of quality with which a task or process is carried out that ultimately leads to higher overall business performance [7]; and in [8], it is explained as doing the right things and producing the intended results; again it is defined as "how well the process actually accomplishes its intended purpose, here again from the customer's point of view" [9] in the implemented participatory budgeting in Port Loko district is that the Study wants to determine. Most countries have reaped the benefits of participatory budgeting and have reported PB to be effective in support of this, and according to [10], their paper reveals that, through the modernization of established practices, the city is greatly benefiting from democratised budgetary activities, transparency for its citizens and its managers even though participatory budgeting is slow in the UK. Also, according to [11] in their paper, they also noted that participatory budgeting (PB) is a democratic innovation worldwide with a high-stake regarding mobilizing politically inactive locals, a budgetary policy that is effective and efficient as well as positive effects on citizens.

And according to [12] in a most comprehensive based review in the UK, participatory budgeting was most effective when used in conjunction with other community engagement processes, and that the overall confidence in participatory budgeting can only be increased through decision-making processes, which are followed up by the delivery of high-quality projects. Others highlighted the factors that link to councils' effectiveness. According to [13] in their paper, they "suggest that both organizational capacity and political factors" positively influence municipal effectiveness.

Also, according to [14], they purported that "councils that display recurrent patterns of dysfunctional behaviour are likely to be ineffective in their core functions". And in [15], they also said that "in developing countries, improving the quality of government delivery system is quite challenging, but the effective delivery system is crucial in achieving the people's satisfaction level".

The Study wants to determine the effectiveness of participatory budgeting 
implemented by Port Loko District in achieving Community Development (CD); that can only happen when they bring community members to solve problems of their societies [16], as this has become an issue of concern which needed a study.

\section{Objectives}

The objectives of the Study are:

1. To find out the changes that occurred in the achievement of community development goals due to the changes in the effectiveness of participatory budgeting in the Port Loko District Council.

2. To determine the linear relationship between the effectiveness of participatory budgeting and the achievement of community development goals in the Port Loko District Council.

\section{Methodology}

Port Loko district is a district located in the Northern Province of the Country [17], now known as part of the Northwest region. As all other councils in the country, the Port district also has a council that caters to its citizens in its sovereignty and one that benefited from the Japan Social Development Fund (JSDF) to strengthen community mobilization and local council service delivery [18]. With such benefit granted them, the Study wants to investigate the effectiveness of Port Loko District Council in the implementation of this Participatory budgeting project in achieving community development goals.

To achieve this, SPSS 16.0 will be used to run and interpret simple linear regression and analyse the results.

\section{Simple Linear Regression Analysis}

\section{Introduction}

In [19], she said, "regression allows you to estimate how a dependent variable change as the independent variable change and that simple linear regression is used to estimate the relationship between two quantitative variables".

\section{Research Objective}

To find out the changes that occurred in the achievement of community development goals due to the changes in the effectiveness of participatory budgeting in Port Loko District Council.

It is worth noting the impact created by the effectiveness of participatory budgeting in the achievement of community development goals. Hence the Study tried to find out the changes that occurred in the achievement of community development goals due to the changes in the effectiveness of participatory budgeting in the Port Loko District Council.

\section{The Model is as Follows}

Starting with the field data collected, the dependent variable (DV) achievement of community development goals and independent variable (IV); effectiveness of participatory budgeting is having the formula thus:

$$
\mathrm{ACDG}=\beta_{0}+\beta_{1} \text { EffectoPB }+l_{t} .
$$

Where:

$\begin{aligned} \text { ACDG }= & \text { Achievement of Community } \\ & \text { Development Goal } \\ \text { EffectoPB }= & \text { Effectiveness of Participatory } \\ & \text { Budgeting - the independent } \\ & \text { variable (the variable that } \\ & \text { influences ACDG) } \\ = & \text { intercept - the predicted value of } \\ & \text { ACDG when EffectoPB is } 0 \\ = & \text { the regression coefficients- how } \\ & \text { much we expect ACDG to change } \\ & \text { as EffectoPB increases } \\ \boldsymbol{\beta}_{\mathbf{1}} \quad & \text { the error estimate }\end{aligned}$




\section{The Study has the Following Hypothesis}

Null hypothesis $\mathrm{H}_{0}=$ The effectiveness of participatory budgeting in Port Loko District councils is insignificant in the achievement of community development goals.

Alternate hypothesis $\mathrm{H} 1=$ The effectiveness of participatory budgeting in Port Loko District councils is significant in the achievement of community development goals.

Having a (0.05) Significant level, at 95\% confidence interval.

\section{Regression Statistics Tables}

\section{Descriptive Statistics}

The respondents were asked about the effectiveness of participatory budgeting in their local councils and wards with the perceptions. 1 $=$ strongly agreed, $2=$ agreed, $3=$ neutral, $4=$ disagree, and $5=$ strongly disagree. Mean rating was found for each perception.

Table 1. Descriptive Statistics

\begin{tabular}{|l|l|l|l|}
\hline Descriptive Statistics & Mean & Std. Deviation & N \\
\hline Achievement of Community Development Goals & 2.4293 & 1.05596 & 420 \\
\hline Effectiveness of participatory budgeting & 1.9483 & .92645 & 420 \\
\hline
\end{tabular}

Source: SPSS 16.0 ACDG $=\beta_{0}+\beta_{1}$ EffectoPB $+l_{t}$

Table 1 revealed the descriptive statistic for the effectiveness of participatory budgeting in the achievement of community development goals. The study's effectiveness with the mean of 1.95 indicated that the respondents agreed that participatory budgeting is effective in their local council and wards.

Table 2. Model Summary

\begin{tabular}{|l|l|l|l|l|}
\hline \multicolumn{5}{|l|}{ Model Summary } \\
\hline Model & R & R Square & Adjusted R Square & Std. Error of the Estimate \\
\hline 1 & $.978^{\mathrm{a}}$ & .957 & .956 & .22027 \\
\hline \multicolumn{5}{|l}{ a. Predictors: (Constant), Effectiveness of participatory budgeting } \\
\hline
\end{tabular}

Source: SPSS 16.0

Table 3. ANOVA

\begin{tabular}{|c|c|c|c|c|c|c|}
\hline \multicolumn{7}{|c|}{ ANOVA $^{b}$} \\
\hline \multicolumn{2}{|l|}{ Model } & Sum of Squares & df & Mean Square & $\mathbf{F}$ & Sig. \\
\hline \multirow[t]{3}{*}{1} & Regression & 446.929 & 1 & 446.929 & $9.211 \mathrm{E} 3$ & $.000^{\mathrm{a}}$ \\
\hline & Residual & 20.281 & 418 & .049 & & \\
\hline & Total & 467.210 & 419 & & & \\
\hline a. Pred & tors: (Constar & Effectiveness of pa & ticipat & ory budgeting & & \\
\hline
\end{tabular}

Source: SPSS 16.0 
Table 4. The Coefficients

\begin{tabular}{|c|c|c|c|c|c|c|}
\hline \multicolumn{7}{|c|}{ Coefficients $^{\mathbf{a}}$} \\
\hline & & \multicolumn{2}{|c|}{$\begin{array}{l}\text { Unstandardized } \\
\text { Coefficients }\end{array}$} & \multirow{2}{*}{ 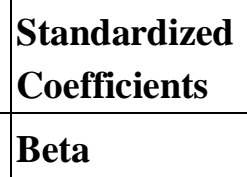 } & \multirow[b]{2}{*}{$\mathbf{t}$} & \multirow[b]{2}{*}{ Sig. } \\
\hline \multicolumn{2}{|c|}{ Model } & B & Std. Error & & & \\
\hline \multirow[t]{2}{*}{1} & (Constant) & .257 & .025 & & 10.274 & .000 \\
\hline & $\begin{array}{l}\text { Effectiveness of } \\
\text { participatory budgeting }\end{array}$ & 1.115 & .012 & .978 & 95.975 & .000 \\
\hline
\end{tabular}

Source: SPSS 16.0

Table 5. Summary of Regression Results

\begin{tabular}{|c|c|c|c|c|c|c|}
\hline \multicolumn{7}{|c|}{\begin{tabular}{|c|} 
Coefficients $^{\mathrm{a}}$ \\
\end{tabular}} \\
\hline & & \multicolumn{2}{|c|}{$\begin{array}{l}\text { Unstandardized } \\
\text { Coefficients }\end{array}$} & \multirow{2}{*}{\begin{tabular}{|l} 
Standardized \\
Coefficients
\end{tabular}} & \multirow[b]{2}{*}{$\mathbf{t}$} & \multirow[b]{2}{*}{ Sig. } \\
\hline \multicolumn{2}{|c|}{ Model } & B & Std. Error & & & \\
\hline \multirow[t]{2}{*}{1} & (Constant) & .257 & .025 & & 10.274 & .000 \\
\hline & EFFECTIVENESS OPB & 1.115 & .012 & .978 & 95.975 & .000 \\
\hline & \multicolumn{6}{|l|}{ R Square .957} \\
\hline & \multicolumn{6}{|l|}{ Adjusted R Square .956} \\
\hline & \multicolumn{6}{|l|}{ F 9.211E3 } \\
\hline & \multicolumn{6}{|l|}{ Sig. . $000^{\mathrm{a}}$} \\
\hline \multicolumn{7}{|c|}{ a. Dependent Variable: Achievement of Community Development Goals } \\
\hline
\end{tabular}

Source: SPSS 16.0

The decision rule is to reject the null hypothesis and accept the alternative if the sig. The value of the variables under study is lower than (0.05) level of significance.

Table 5 above showed the hypothesis tests if the effectiveness of participatory budgeting in the Port Loko District Council has an impact on the achievement of community development goals. The dependent variable achievement of community development goals was regressed on predicting variable Effectiveness of participatory budgeting to test hypothesis $\mathrm{H} 1$. Effectiveness of participatory budgeting significantly predicted ACDG, F $(1,418)$ $=9.211 \mathrm{E} 3, \mathrm{P}<0.000$, which indicates that Effect OPB can play a significant role in shaping
$\operatorname{ACDG}(b=1.115, \mathrm{p}<0.000)$. These results clearly direct the positive affect of the Effect OPB. Moreover, the $\mathrm{R} 2=0.957$ depicts that the model explains $95.7 \%$ of the variance in ACDG, which means we accept the alternate hypothesis and reject the null hypothesis.

\section{Correlation Analysis}

\section{Introduction}

According to [20], he said "a correlation between variables indicates that as one variable changes in value, the other variable tends to change in a specific direction and that Pearson's correlation coefficients measure only linear relationships". 


\section{Research Objective}

The research objective seeks to find out the linear relationship between the effectiveness of participatory budgeting in the achievement of community development goals in the Port Loko District Council by testing the following hypothesis using the Pearson correlation test:

Null hypothesis H0: The effectiveness of participatory budgeting (Effect OPB) has no linear relationship with the achievement of community development goals (ACDG) in the Port Loko district council.
Alternate hypothesis H1: The effectiveness of participatory budgeting (Effect OPB) has a linear relationship with the achievement of community development goals (ACDG) in the Port Loko district council.

Where: $\mathrm{ACDG}=$ Achievement of Community Development Goal.

EffictoPB $=$ Effectiveness of Participatory Budgeting.

Having a (0.05) Significant level, at 95\% confidence interval.

Table 6. Correlations between Achievement of Community Development Goals and that of Effectiveness of Participatory Budgeting

\begin{tabular}{|l|l|l|l|}
\hline \multicolumn{2}{|l|}{ Correlations } & $\begin{array}{l}\text { Achievement of } \\
\text { Community } \\
\text { Development Goals }\end{array}$ & $\begin{array}{l}\text { Effectiveness of } \\
\text { Participatory } \\
\text { Budgeting }\end{array}$ \\
\hline Pearson Correlation & $\begin{array}{l}\text { Achievement of Community } \\
\text { Development Goals }\end{array}$ & 1.000 & .978 \\
\cline { 2 - 4 } & $\begin{array}{l}\text { Effectiveness of Participatory } \\
\text { Budgeting }\end{array}$ & .978 & 1.000 \\
\hline \multirow{2}{*}{ Sig. (1-tailed) } & ACDG &. & .000 \\
\cline { 2 - 4 } & Effectiveness OPB & .000 &. \\
\hline \multirow{2}{*}{$\mathrm{N}$} & ACDG & 420 & 420 \\
\cline { 2 - 4 } & Effectiveness OPB & 420 & 420 \\
\hline
\end{tabular}

Source: SPSS 16.0

Table 6 result revealed that the correlation between the effectiveness of participatory budgeting and achievement of community development goals, the value showed a positive correlation (0.978) and also found to be statically significant going with the $\mathrm{P}$-value (0.000).

\section{Results and Discussions}

The results from the study respondents are analysed from the descriptive statistics table (1), regression summary table (5), and the correlation table (6), respectively. From table 1 result, it was revealed by the respondents that the participatory budgeting implemented by Port Loko District Council were effective even though with the observed challenges. It was also revealed from table 5 the linear regression table an R2 result of (0.957) which reads as $95.7 \%$ changes in the achievement of community development goals is as a result of effective participatory budgeting practices. Or $95.7 \%$ changes in the dependent variable are as a result of the independent variable. Lastly, from the correlational test results, it was revealed that there is a strong correlation between the effectiveness of participatory budgeting and the achievement of community development goals.

\section{Conclusion}

The Study on the effectiveness of participatory budgeting in the Port Loko District Council in relation to the achievement of community development goals showed that participatory budgeting is effective, had a 
positive relationship with a strong correlation between them. This means it is applicable to any other district council in Sierra Leone and all government ministries, departments, and agencies (MDAs).

\section{Conflict of Interest}

The authors declare no conflict of interest in the manuscript.

\section{References}

[1] ACT, L. G. (2004, 03 1). The Local Government Act, 2004. Retrieved 11 01, 2020, from The Local Government Act, 2004-Sierra Leone Web: http://www.sierra-leone.org/Laws/2004-1p.pdf.

[2] Eisenstein, L. (2016, 3 6). The Importance of Effective and Efficient Local Governments. Retrieved 06 23, 2021, from Diligent Insights: https://insights.diligent.com/workload-

management/the-importance-of-effective-andefficient-local-governments/.

[3] LGA. (2020). Participatory Budgeting. Retrieved 11 1, 2020, from Local Government Association: https://www.local.gov.uk/topics/devolution/engagin g-citizens-devolution/approaches-civic-anddemocratic-engagement- 0 .

[4] Campbell, M., Escobar, O., Fenton, C., \& Craig, a. P. (2018, 7 3). The impact of participatory budgeting on health and wellbeing: a scoping review of evaluations. Retrieved 06 24, 2021, from BMC Public Health:

https://bmcpublichealth.biomedcentral.com/articles/ 10.1186/s12889-018-5735-8.

[5] Sesay, J. B. (2018, 11 4). Local Councils, Service Delivery and their Welfare! Retrieved 11 09, 2020, from Sierra Express Media: https://sierraexpressmedia.com/?p=86005.

[6] Dauda, S. J. (2019). Personnel Management in Local Government Performance- A Case Study of Bo City Council, Sierra Leone. International Journal of Management and Fuzzy Systems, 1-6.

[7] Accounting Dictionary. (n.d.). What is Effectiveness? Retrieved 11 4, 2020, from My Accounting Course:

\section{Acknowledgement}

I take this opportunity to thank my supervisors Prof. Dr. S. Subadra and Prof. Dr. S.P. Sreekala who helped me reaching thus far in this publication.

https://www.myaccountingcourse.com/accountingdictionary/effectiveness.

[8] Kolmar, C. (2020, 11 16). Efficiency vs. Effectiveness: what's the difference? (with examples). Retrieved 06 23, 2021, from ZIPPA: https://www.zippia.com/advice/efficiency-vseffectiveness/.

[9] Principle of Management. (2016, 05 30). Principles of Management Efficiency and effectiveness. Retrieved 11 04, 2020, from Principles of Management:

https://www.peoi.org/Courses/Coursesen/mgt/fram9. html\#: :text=Efficiency\%20and\%20effectiveness $\%$ 20are $\% 20$ often $\% 20$ considered $\% 20$ synonyms $\% 2 \mathrm{C} \%$ 20but\%20they\%20mean,is\%20doing\%20the\%20rig ht\%20things.\&text $=$ This $\% 20$ includes $\% 20$ managem ent $\% 20$ processes $\% 20$ as $\% 20$ well $\% 20$ as $\% 2$.

[10] Brun-Martos, M. I., \& Lapsley, a. I. (2016). Democracy, governmentality, and transparency: participatory budgeting in action. Public Management Review, 1006-1021.

[11] Schneider, S. H., \& Busse, a. S. (2018). Participatory Budgeting in Germany - A Review of Empirical Findings. International Journal of Public Administration, 259-273.

[12] Harkins, C., \& Egan, a. J. (2012, 03). The Role of Participatory Budgeting In Promoting Localism And Mobilising Community Assets. Retrieved 11 2, 2020, from Glasgow Centre for Population Health: https://www.gcph.co.uk/assets/0000/3145/GCPH_Pa rticipatory_Budgeting_FINAL.pdf.

[13] Piña, G., \& Avellaneda, a. C. (2017, 02). Local Government Effectiveness:. Retrieved 06 24, 2021, from Research Gate: 
https://www.researchgate.net/publication/318348239 _Local_Government_Effectiveness_Assessing_the_ Role_of_Organizational_Capacity.

[14] Nelson, K. L., Gabaris, G. T., \& Davis, a. T. (2011, 11 2). What Makes Municipal Councils Effective?: An Empirical Analysis of How Council Members Perceive Their Group Interactions and Processes. Retrieved 06 24, 2021, from SAGE Journals:

https://journals.sagepub.com/doi/abs/10.1177/01603 23X11424913? journalCode=slgb.

[15] Osman, M. M., Bachok, S., Bakri, N. I., \& Harun, a. N. (2017, 1 4-5). Government Delivery System: Effectiveness of local authorities in Perak, Malaysia. Retrieved 06 24, 2021, from Science Direct:

https://pdf.sciencedirectassets.com/277811/1-s2.0-

S1877042814X00480/1-s2.0-

S1877042814055219/main.pdf?X-Amz-Security-

Token=IQoJb3JpZ2luX2VjEDoaCXVzLWVhc3Qt

MSJIMEYCIQC4jw7lvp7wjCniSScskWcwt02f8urv h5AfDCnGnX81XgIhAL6yXN2a69c50B3irOfx1U Xn9xHQfJrmBy2e8v6EHDx8.

[16] Straza, M. (2018, 12 17). Community Development: What It Is, Its Importance, and How to Contribute in Your City. Retrieved 11 1, 2020, from

\section{Straza Consulting:}

https://www.consultstraza.com/community-

development-what-it-is-its-importance-and-how-tocontribute-in-your-city/.

[17] OCHA Services. (2015, 12 29). Sierra Leone: Port Loko District Profile (29 December 2015). Retrieved 06 18, 2021, from reliefweb: https://reliefweb.int/report/sierra-leone/sierra-leoneport-loko-district-profile-29-december-2015.

[18] Kanu, K. (2017, 08 11). US\$2,750,000 JSDF Grant to Sierra Leone to Strengthen Community Mobilization and Service Delivery. Retrieved 06 18, 2021, from Cocorioko: https://cocorioko.net/us2750000-jsdf-grant-to-sierraleone-to-strengthen-community-mobilization-andservice-delivery/.

[19]Bevans, R. (2020, 02 19). An introduction to simple linear regression. Retrieved 06 08, 2021, from Scribbr: https://www.scribbr.com/statistics/simplelinear-regression/.

[20]Frost, J. (n.d.). Interpreting Correlation Coefficients. Retrieved 06 08, 2021, from Statistics By Jim:

https://statisticsbyjim.com/basics/correlations/. 